\title{
EFFECT OF TEMPERATURE, TIME, AND ASPARAGINASE ON ACRYLAMIDE FORMATION AND PHYSICOCHEMICAL PROPERTIES OF BREAD
}

\author{
N. Samadi Ghorbani, M. Mazaheri Tehrani*, M.H. Haddad Khodaparast \\ and R. FARHOOSH \\ Department of Food Science and Technology, Ferdowsi University of Mashhad (FUM), Mashhad, Iran
}

(Received: 1 April 2018; accepted: 1 September 2018)

The aim of the current paper was to elucidate the influence of temperature and time on acrylamide formation and physico-chemical characteristics of bread. Additionally, the effect of asparaginase addition to bran was evaluated. With increasing baking time and temperature, the amount of acrylamide $\left(\mu \mathrm{g} \mathrm{kg}^{-1}\right)$ increased. The results indicated that the acrylamide concentration in treated samples with asparaginase was significantly less than those without asparaginase treatment. Based on Pearson' test, it was found that there was a significant correlation between baking temperature and acrylamide concentration $(\mathrm{R}=0.99, \mathrm{P}=0.025$; and $\mathrm{R}=0.98, \mathrm{P}=0.026$ for the samples prepared by baking for $2.5 \mathrm{~min}$ and $3 \mathrm{~min}$, respectively). The firmness of bread samples increased with increasing baking temperature $(\mathrm{P}>0.05)$, while asparaginase addition did not significant affect the textural characteristics of the final product. Breads baked at $320^{\circ} \mathrm{C}$ for 3 min were more acceptable by the sensory panel in terms of their texture and chewiness, whereas the samples baked at $370^{\circ} \mathrm{C}$ for $2.5 \mathrm{~min}$ had the lowest score in comparison to other evaluated samples.

Keywords: acrylamide, asparaginase, bran, bread, textural properties

Maillard reaction is the most important chemical reaction occurring during the production of bakery products. Brown colour and tasty flavour of baked products arise from Maillard reaction. It has also been demonstrated that this reaction is the main reason for formation of compounds with harmful effects like acrylamide in heated foods (PEDRESCHI et al., 2011). It has been found that an extensive range of food products like bread, coffee, biscuits, and fried potato contain high amount of acrylamide (RoséN \& HELLENÄs, 2002). The major reactants resulting in the acrylamide formation are asparagine and reducing sugars (fructose and glucose) (Mottram et al., 2002; BecalsKi et al., 2003). Acrylamide is a carcinogenic compound, it is, therefore, very important to decrease the concentration of this compound in mentioned products.

Based on available literature, there are several techniques for reducing the amount of acrylamide in breads. Haase and co-workers (2003) reported that the concentration of acrylamide in baked products is mainly dependent on baking temperature and flour milling intensity. SURDYK and co-workers (2004) investigated the effect of fructose and asparagine on the formation of acrylamide in white leavened bread. The authors found that there is a strong correlation between the formation of acrylamide and crust colour. An increase in ash content of flour resulted in an increase in the amount of acrylamide. AMREIN and co-workers (2004) examined the effect of asparaginase, sodium, and ammonium hydrogen-carbonate on the formation of acrylamide in gingerbread. They found that utilization of asparaginase in dough led to a considerable reduction in acrylamide concentration, and had no undesirable effect on taste and colour properties of this product. Unlike previous research, in this work, asparaginase directly was added to bran and its effect on acrylamide formation and physicochemical

\footnotetext{
* To whom correspondence should be addressed.

Phone: +98 513 8805770; fax: +98 513 8805781; e-mail: mmtehrani@um.ac.ir
} 
properties of bread was investigated. Furthermore, the effect of temperature and time of baking on these properties was evaluated to suggest an appropriate way to reduce acrylamide content.

\section{Materials and methods}

\subsection{Chemicals}

Commercial wheat flour and wheat bran were obtained from the Zarrin Co., Khorasan, Iran. Dried active yeast was obtained from Razavi Co., Khorasan, Iran. Asparaginase enzyme was purchased from Sigma Co (St. Louis, MO). All chemicals used in this study were of analytical grade and purchased from Merck (Darmstadt, Germany). Acrylamide and [2,3,3-d3]acrylamide standards were obtained from Sigma (St. Louis, MO).

\subsection{Bran treatment}

One kilogram of bran was mixed with 41 of water in a beaker and covered with aluminium foil. Asparaginase (1000 $\mathrm{U} \mathrm{kg}^{-1}$ of bran) was dispersed in the deionized water to assure a homogeneous distribution in the dough when added to the mixture. The optimum temperature and $\mathrm{pH}$ for the activity of asparaginase is $40-60{ }^{\circ} \mathrm{C}$ and 7 , respectively (PEDRESCHI et al., 2008). Therefore, the addition of asparaginase to the samples was carried out at $45^{\circ} \mathrm{C}$ and $\mathrm{pH}=7$. The samples were incubated at $37^{\circ} \mathrm{C}$ for $40 \mathrm{~min}$ and then allowed to stand at $75^{\circ} \mathrm{C}$ for $5 \mathrm{~min}$ for deactivation of enzymes.

\subsection{Baking process}

A model system containing flour, water, bran (with and without enzymatic treatment), salt (1 $\mathrm{g} / 100 \mathrm{~g}$ flour$)$, and commercial brewer's yeast as leavening agent $(1 \mathrm{~g} / 100 \mathrm{~g}$ flour $)$ was used. The ingredients were mixed in the bowl of a mixer (at room temperature for $5 \mathrm{~min}$ ), the dough was shaped manually, and then was allowed to leaven for $120 \mathrm{~min}$ at ambient temperature (NAJAFABADI et al., 2014). A commercial baking oven (Revent, Revent International $\mathrm{AB}$, Sweden) was used for baking of fermented dough at different temperatures and times (Table 1). After cooling, some physicochemical properties of samples such as colour, acrylamide content, as well as textural and sensory properties were determined.

\subsection{Analysis of acrylamide}

Acrylamide measurement was carried out based on the Norwegian Air Research Institute (NILU) by the assay described by Rosén and HeLlenäs (2002), using high-resolution time of flight mass spectrometry instead of tandem mass spectrometry. Briefly, $3 \mathrm{~g}$ of the sample was homogenized in water $(30 \mathrm{ml})$ containing d3-acrylamide $\left(100 \mathrm{~g} \mathrm{l}^{-1}\right)$ (as an internal standard). Sonication (30 min) was used to extract acrylamide. The purification of extract was performed by adding 500-500 $\mu \mathrm{l}$ of Carrez I and Carrez II reagents. Centrifugation (at 4000 r.p.m. for $10 \mathrm{~min}$ ) was done to remove the precipitates, and the supernatant $(3 \mathrm{ml})$ was filtered using SPE columns, Isolute Multimode, $300 \mathrm{mg}$ (IST, Hengoed, UK), pretreated with acetonitrile $(1 \mathrm{ml})$ and water $(2-2 \mathrm{ml})$. The first portion $(1 \mathrm{ml})$ was discarded, and the remaining portion was collected and passed through a $0.22-\mu \mathrm{m}$ syringe filter Millex-GS (Millipore, Bedford, USA). The filtrate $(500 \mu \mathrm{l})$ was passed through a Microcon YM-3 centrifuge spin filter (Millipore, Bedford, USA) with 13000 r.p.m. for 10-20 min. In order to separate acrylamide 
from the sample matrix, a high-performance liquid chromatography system (Agilent HP1100) fitted with a Waters Atlantis pre-column in front of the analytical column was used. The detector utilized for this measurement was a Micromass LCT orthogonal Time-Of-Flight (TOF) mass spectrometer equipped with a Z-spray ion source operated in the atmospheric pressure chemical ionization positive mode APCI $(+)$.

Table 1. Processing conditions of bread

\begin{tabular}{lccc}
\hline Sample & Temperature $\left({ }^{\circ} \mathrm{C}\right)$ & Time $(\mathrm{min})$ & Enzyme concentration $\left(\mathrm{U} \mathrm{kg}^{-1}\right)$ \\
\hline T1t1E0 & 270 & 2.5 & 0 \\
T1t1E1 & 270 & 2.5 & 1000 \\
T1t2 E0 & 270 & 3 & 0 \\
T1t2 E1 & 270 & 3 & 1000 \\
T2t1 E0 & 320 & 2.5 & 0 \\
T2t1 E1 & 320 & 2.5 & 1000 \\
T2t2 E0 & 320 & 3 & 0 \\
T2t2 E1 & 320 & 3 & 1000 \\
T3t1 E0 & 370 & 2.5 & 0 \\
T3t1 E1 & 370 & 2.5 & 1000 \\
T3t2 E0 & 370 & 3 & 0 \\
T3t2 E1 & 370 & 3 & 1000 \\
\hline
\end{tabular}

T1: temperature of $270{ }^{\circ} \mathrm{C}$; T2: temperature of $320^{\circ} \mathrm{C}$; T3: temperature of $370{ }^{\circ} \mathrm{C}$

$\mathrm{t} 1$ : time of $2.5 \mathrm{~min} ; \mathrm{t} 2$ : time of $3 \mathrm{~min}$

E0: Enzyme concentration of $0 \mathrm{U} \mathrm{kg}^{-1}$; E1: enzyme concentration of $1000 \mathrm{U} \mathrm{kg}^{-1}$

\subsection{Chemical analysis of flour}

Moisture, protein, fat, and ash contents of the samples were measured based on AOAC (1990) assay. For moisture content measurement, the samples were dried at $70{ }^{\circ} \mathrm{C}$ for $16 \mathrm{~h}$.

\subsection{Colour properties}

Colour attributes were evaluated in CIE $L^{*} a^{*} b^{*}$ colour space units using a colorimeter (Minolta, Italy). The colorimeter was calibrated with white standard. Colour parameter determinations were carried out on three samples, and the mean values were reported. The colour difference $\left(\mathrm{DE}^{*}\right)$ was investigated compared to the results obtained from the untreated sample. The colour difference $(\Delta \mathrm{E})$ was quantified as follows:

$$
\Delta \mathrm{E}=\left(\Delta \mathrm{L}^{2}+\Delta \mathrm{a}^{2}+\Delta \mathrm{b}^{2}\right)^{1 / 2}
$$

\subsection{Textural analysis}

Textural properties of bread samples were evaluated according to the earlier described method of Pourfarzad and co-workers (2011) with some modifications. Penetration test was used to analyse textural characteristics of the baked samples. A QTS texture analyzer (CNS Farnell, Hertfordshire, UK) was employed to record the force needed to drive a probe with 4 $\mathrm{cm}$ diameter and $1.8 \mathrm{~cm}$ height through the bread crust (at a velocity of $30 \mathrm{~mm} \mathrm{~min}^{-1}$ ). The 
probe descended $30 \mathrm{~mm}$ (a sufficient distance to pass through the slice of $10 \times 10 \mathrm{~cm}$ of bread) and the trigger force was set at $0.05 \mathrm{~N}$.

\subsection{Sensory analyses}

Sensory analyses of the bread samples were performed $24 \mathrm{~h}$ after baking by 10 trained panellists. Several sensory properties including taste, colour, texture, and chewiness were evaluated. A seven-point hedonic scale [1 (not at all) to 7 (totally)] was used. Bread samples were considered acceptable if their mean scores for the acceptability were above 5 (LAZARIDOU et al., 2007).

\subsection{Statistics}

All measurements were carried out in at least three parallels. All data were subjected to analysis of variance (ANOVA), and the comparison of means was carried out by using the Duncan test (SPSS software, version 21.0). Means were considered significantly different at $\mathrm{P}<0.05$.

\section{Results and discussions}

\subsection{Acrylamide content}

The effects of temperature, time, and asparaginase addition on the formation of acrylamide are presented in Figures 1 and 2. It can be observed that for a constant baking time, following an increase in temperature, the amount of acrylamide $\left(\mu \mathrm{g} \mathrm{kg}^{-1}\right)$ showed an increasing trend. The presence of moisture in bread formulation leads to a decrease in acrylamide content of baked samples (MоттRAm et al., 2002). Therefore, this increasing trend may be due to a decrease of moisture in the samples. Similarly, an increase in baking time resulted in elevation of acrylamide content. The effect of temperature on acrylamide formation was greater than that observed for time of baking. Likewise, SURDYK and co-workers (2004) reported that both baking time and baking temperature led to an increase in acrylamide content of yeastleavened bread. In this study, no decrease in the concentration of acrylamide was observed either for long time baking process or high baking temperature, despite of several authors reporting that prolonged heating led to a decrease in acrylamide concentration. This decreasing effect related to polymerization and reaction with other compounds was reported for several food products such as roasted coffee (ŞENYuva \& GöKMEN, 2005), rye flat bread (BRÅTHEN \& KNUTSEn, 2005), and bread crisp (CAPUANo et al., 2009).

Based on the literature, there is a positive relation between the formation of acrylamide and the baking temperature (BR̊̊THEN \& KNUTSEN, 2005; AHRNÉ et al., 2007). With increasing baking temperature from 270 to $370{ }^{\circ} \mathrm{C}$, the concentration of acrylamide increased. The results of Pearson test demonstrated that there was a significant correlation between baking temperature and acrylamide concentration $(\mathrm{R}=0.99, \mathrm{P}=0.025$ and $\mathrm{R}=0.98, \mathrm{P}=0.026$ for the samples baked for $2.5 \mathrm{~min}$ and $3 \mathrm{~min}$, respectively).

During baking process, Maillard reaction and caramelization are the main chemical reactions happening. The amounts of acrylamide in bread samples with and without asparaginase are presented in Figure 2. It is clear that the concentration of acrylamide in treated samples with asparaginase was significantly less than those without asparaginase treatment, making this enzyme a possible agent for acrylamide reduction in breads. 
Asparaginase hydrolyzes the amide of asparagine, an important precursor of acrylamide formation, and as a result, decreases the concentration of this compound. The results of the analysis of baked bread for acrylamide content during normal process of baking indicated that when bread was prepared with asparaginase treated dough, the amount of acrylamide decreased. About 95 and $97 \%$ reductions were reported at 200 and $300 \mathrm{U}$ of enzyme, respectively. The influences of process conditions and flour type on a bread crisp model system were investigated by CAPUANO and co-workers (2009). The authors reported that asparaginase reduced the amount of acrylamide up to $88 \%$ and had no influence on browning development and antioxidant properties.

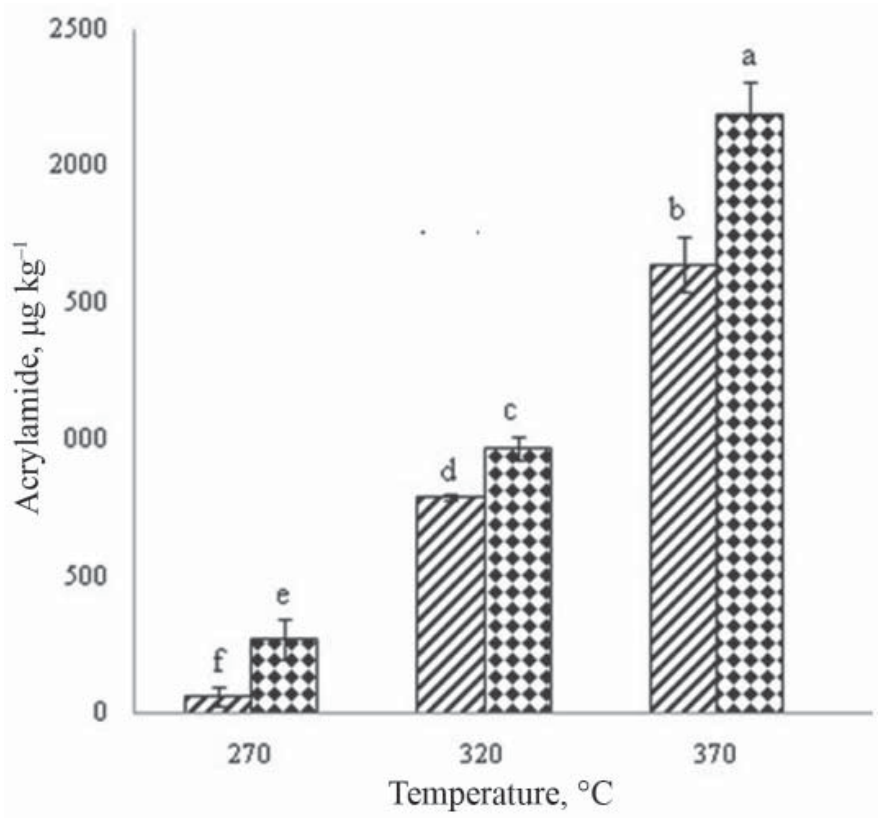

Fig. 1. Change of acrylamide content of baked breads (without asparaginase) at different temperatures and time of baking compared to control $2.5 \mathrm{~min} ; 3 \mathrm{~min}$

Columns with different lowercase letters differ significantly at $\mathrm{P}<0.05$

\subsection{Colour properties}

The consumer acceptability of food products could be influenced by the optical attributes. In order to evaluate the colour properties of baked breads, $L^{*}$ (lightness), $a^{*}$ (green-red), $b^{*}$ (blue-yellow), and total colour difference $(\Delta \mathrm{E})$ were determined (Table 2). Based on the obtained results, an increase in the baking time and temperature led to a decrease in the magnitude of the $L^{*}$ value, which could be related to Maillard's reaction between amino acids and reducing sugars. A more value of $L^{*}$, which showed the ratio of white to black colour illustrated that the increasing baking temperature resulted in depressing the level of whiteness. The same result has been obtained by SABovics and co-workers (2014). On the other hand, a slight increase in $a^{*}$ parameter of the sample was observed when baking temperature increased, demonstrating that the degree of redness increased. Similar trend was observed for the effect of temperature on acrylamide content. As observed in Table 2, the 
addition of asparaginase to bread formulation had no significant effect on colour parameters of the samples. Similar results have been reported by CAPUANO and co-workers (2009) and KUKUROVA and co-workers (2009).
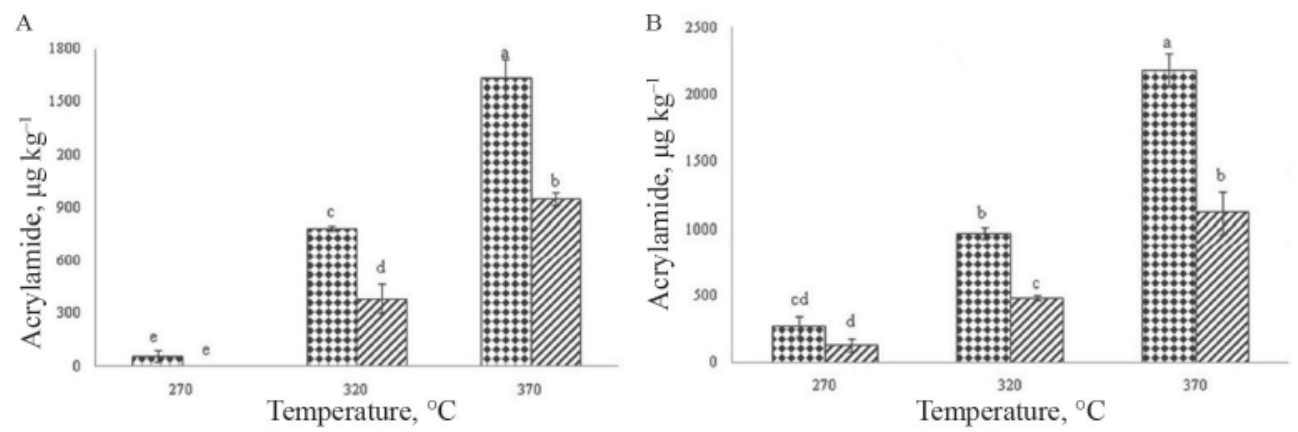

Fig. 2. Change of acrylamide content of bread with $\left(\mathrm{E}_{1}\right)$ and without asparaginase $\left(\mathrm{E}_{0}\right)$ as a function of temperature at times $2.5 \min (\mathrm{A})$ and $3 \min (\mathrm{B})$; $\mathrm{E} 0$; $\mathbb{Z}_{\text {: }} \mathrm{E} 1$

Columns with different lowercase letters differ significantly at $\mathrm{P}<0.05$

Table 2. Colour properties of the different bread formulations with or without asparaginase addition

\begin{tabular}{|c|c|c|c|c|c|c|}
\hline \multirow[t]{2}{*}{ Treatment } & \multicolumn{2}{|c|}{$L^{*}$} & \multicolumn{2}{|c|}{$a^{*}$} & \multicolumn{2}{|c|}{$b^{*}$} \\
\hline & E0 & E1 & E0 & E1 & E0 & E1 \\
\hline T1t1 & $63.95 \pm 0.11^{\mathrm{a}}$ & $63.19 \pm 0.94^{\mathrm{ab}}$ & $-5.73 \pm 0.33^{\mathrm{d}}$ & $6.26 \pm 0.08^{\mathrm{d}}$ & $14.4 \pm 0.55^{\mathrm{d}}$ & $13.1 \pm 0.37^{\mathrm{c}}$ \\
\hline T1t2 & $63.94 \pm 1.67^{\mathrm{a}}$ & $62.79 \pm 1.03^{\mathrm{ab}}$ & $-6.37 \pm 0.23^{\mathrm{d}}$ & $5.78 \pm 0.03^{\mathrm{d}}$ & $13.78 \pm 0.30^{\mathrm{d}}$ & $14.47 \pm 0.02^{\mathrm{c}}$ \\
\hline $\mathrm{T} 2 \mathrm{t} 1$ & $64.25 \pm 0.00^{\mathrm{a}}$ & $63.71 \pm 0.10^{\mathrm{a}}$ & $-5.88 \pm 0.5^{\mathrm{d}}$ & $6.09 \pm 0.55^{\mathrm{d}}$ & $13.87 \pm 0.95^{\mathrm{d}}$ & $14.75 \pm 0.78^{\mathrm{c}}$ \\
\hline $\mathrm{T} 2 \mathrm{t} 2$ & $57.37 \pm 0.92^{\mathrm{b}}$ & $59.24 \pm 3.05^{\mathrm{b}}$ & $-3.95 \pm 0.87^{\mathrm{c}}$ & $3.28 \pm 0.47^{\mathrm{c}}$ & $18.95 \pm 1.13^{\mathrm{c}}$ & $20.06 \pm 0.08^{b}$ \\
\hline T3t1 & $46.98 \pm 0.26^{\mathrm{c}}$ & $51.15 \pm 0.82^{\mathrm{c}}$ & $-0.14 \pm 0.69^{\mathrm{b}}$ & $-1.15 \pm 0.17^{\mathrm{b}}$ & $21.71 \pm 1.17^{\mathrm{ab}}$ & $22.29 \pm 1.29^{\mathrm{a}}$ \\
\hline T3t2 & $34.94 \pm 0.36^{\mathrm{d}}$ & $35.49 \pm 1.83^{\mathrm{d}}$ & $4.61 \pm 0.16^{\mathrm{a}}$ & $4.54 \pm 0.02^{\mathrm{a}}$ & $20.27 \pm 0.65^{\mathrm{bc}}$ & $20.73 \pm 0.82^{\mathrm{ab}}$ \\
\hline
\end{tabular}

T1: temperature of $270{ }^{\circ} \mathrm{C} ; \mathrm{T} 2$ : temperature of $320^{\circ} \mathrm{C} ; \mathrm{T} 3$ : temperature of $370{ }^{\circ} \mathrm{C}$ t1: time of $2.5 \mathrm{~min}$; $\mathrm{t} 2$ : time of $3 \mathrm{~min}$

E0: Enzyme concentration of $0 \mathrm{U} \mathrm{kg}^{-1}$; E1: enzyme concentration of $1000 \mathrm{U} \mathrm{kg}^{-1}$

Different lowercase letters show significant differences at $\mathrm{P}<0.05$

\subsection{Textural characteristics}

The values of firmness for the samples with and without asparaginase as a function of time and temperature of baking are depicted in Figure 3. The magnitude of firmness increased with increasing baking temperature $(\mathrm{P}>0.05)$, which may be due to higher moisture loss at higher temperature and baking time. Likewise, SABOVICS and co-workers (2014) reported that with increasing baking temperature, the stickiness of bread crumb decreased, but the degree of firmness increased. The same results have been reported by DAS and co-workers (2012). Also, with addition of asparaginase to bread formulation, the values of firmness improved but not significantly $(\mathrm{P}>0.05)$. Therefore, asparaginase addition did not significantly affect the textural characteristics of the final product. 

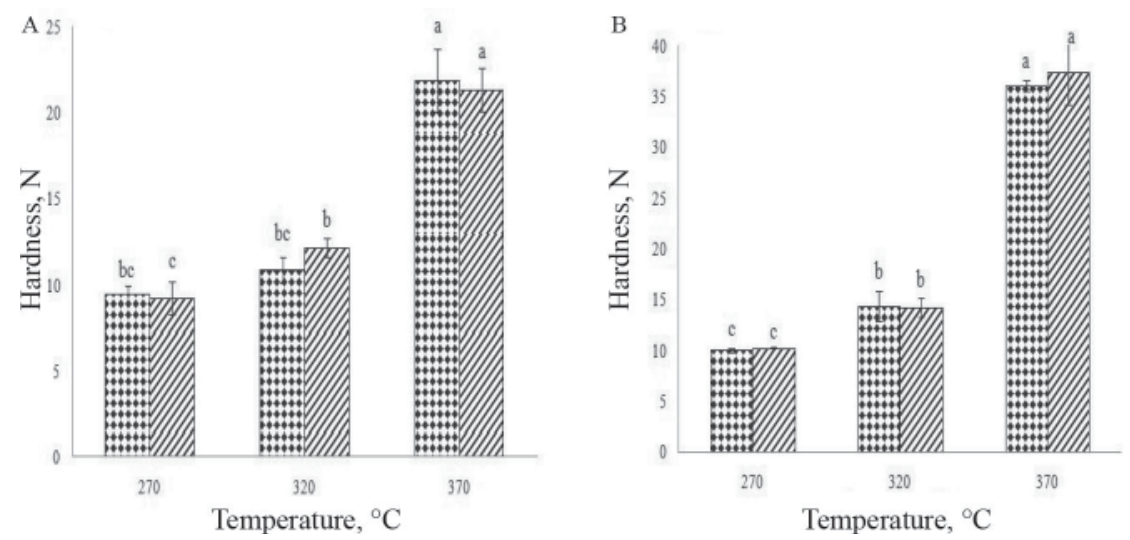

Fig. 3. Effect of different treatments on textural properties of baked breads (baked for $2.5 \min (\mathrm{A})$ and $3 \mathrm{~min}(\mathrm{~B})$ ) 解: 0 ;

Columns with different lowercase letters differ significantly at $\mathrm{P}<0.05$

\subsection{Sensory properties}

The effect of different treatments on taste, chewiness, colour, texture, and overall acceptance of bread is depicted in Figure 4. It can be seen that increasing the temperature and time of baking up to $320^{\circ} \mathrm{C}$, a significant improvement $(\mathrm{P}<0.05)$ in the scores for taste was observed, which may be associated with the Maillard reaction. With further increase in temperature, the score of taste decreased, which may be attributed to the development of a bitter flavour arising from further Maillard reactions. The bread prepared at $320{ }^{\circ} \mathrm{C}$ for $3 \mathrm{~min}$ had the highest score in term of crust colour. Further increase in time and temperature of baking led to a decrease in the colour quality of the samples. Similar to the crust appearance, breads manufactured at $320{ }^{\circ} \mathrm{C}$ for 3 min were more acceptable by the sensory panel in terms of texture and chewiness, whereas the samples at $370{ }^{\circ} \mathrm{C}$ for $2.5 \mathrm{~min}$ had the lowest score among evaluated samples.

On the other hand, the incorporation of asparagines had no significant influence on sensory properties of bread samples. This result is consistent with those cited by CAPUANO and co-workers (2009), and KUMAR and co-workers (2014), who indicated that asparaginase had no considerable effect on colour and other physical properties of breads. In general, the samples prepared at $320^{\circ} \mathrm{C}$ for 3 min scored best among tested samples. However, since the samples prepared at $320^{\circ} \mathrm{C}(3 \mathrm{~min})$ and $320^{\circ} \mathrm{C}(2.5 \mathrm{~min})$ had high scores, their sensory characteristics were realized to be more acceptable. 

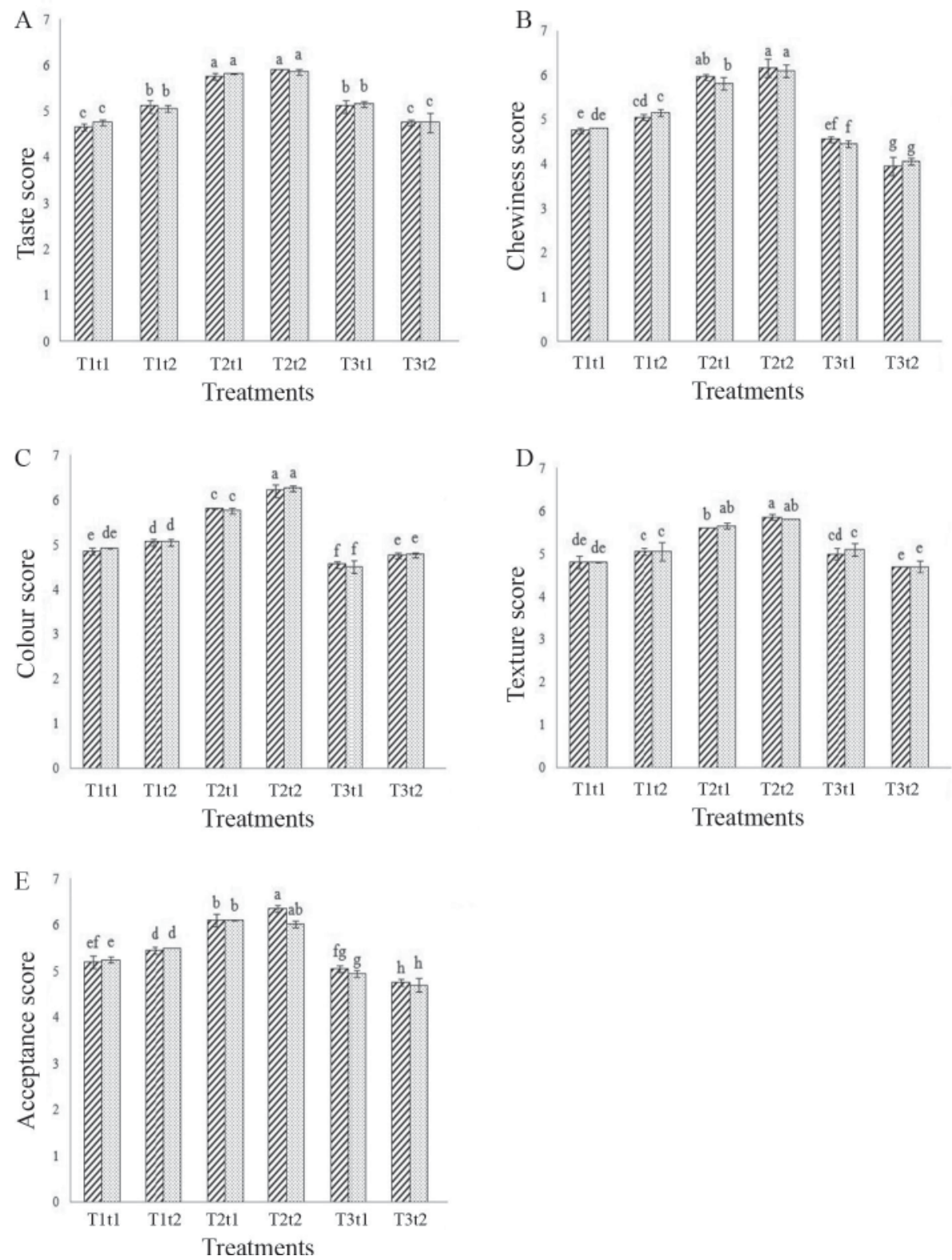

Fig. 4. Effects of different treatments on taste (A), chewiness (B), colour (C), texture (D), and overall acceptance (E) of bread, ש: E0; 漗: E1

\section{Conclusions}

This study reported a technique to diminish acrylamide formation in bread during industrial baking process. Acrylamide formation demonstrated a strong temperature dependency. Direct addition of asparaginase to bran also led to a significant decrease in the concentration of 
acrylamide. Overall, baking of bread comprising asparaginase at mild temperature can be used to decrease acrylamide concentration in the final product.

The authors wish to thank Mashhad Baking Industries Co for their assistance in conducting this project.

\section{References}

Ahrné, L., Andersson, C.-G., Floberg, P., Rosén, J. \& Lingnert, H. (2007): Effect of crust temperature and water content on acrylamide formation during baking of white bread: steam and falling temperature baking. $L W T-$ Food Sci. Technol., 40(10), 1708-1715.

Amrein, T.M., Schönbächler, B., Escher, F. \& Amadò, R. (2004): Acrylamide in gingerbread: Critical factors for formation and possible ways for reduction. J. Agr. Food Chem., 52, 4282-4288.

AOAC (1990): Official methods of analysis. Association of Official Analytical Chemists, Washington DC, USA. Method No. 925.09, 923.03, 922.06, 920.87

Becalski, A., Lau, B.P.-Y., Lewis, D. \& Seaman, S.W. (2003): Acrylamide in foods: Occurrence, sources, and modeling. J. Agr. Food Chem., 51, 802-808.

BRÅthen, E. \& KNUTSEN, S.H. (2005): Effect of temperature and time on the formation of acrylamide in starch-based and cereal model systems, flat breads and bread. Food Chem., 92, 693-700.

Capuano, E., Ferrigno, A., Acampa, I., Serpen, A., Açar, Ö.Ç., Gökmen, V. \& Fogliano, V. (2009): Effect of flour type on Maillard reaction and acrylamide formation during toasting of bread crisp model systems and mitigation strategies. Food Res. Int., 42, 1295-1302.

DAs, L., RAYCHAUDhri, U. \& CHAKRABORTY, R. (2012): Effects of baking conditions on the physical properties of herb bread using RSM. Int. J. Food Agr. Vet. Sci, 2, 106-114.

Hatse, N., Matthäus, B. \& Vosmann, K. (2003): Minimierungsansätze zur Acrylamid-Bildung in pflanzlichen Lebensmitteln: aufgezeigt am Beispiel von Kartoffelchips. Deut. Lebensm.-Rundsch., 99(3), 87-90.

Kukurova, K., Morales, F.J., Bednarikova, A. \& Ciesarova, Z. (2009): Effect of L-asparaginase on acrylamide mitigation in a fried-dough pastry model. Mol. Nutr. Food Res., 53(12), 1532-1539.

Kumar, N.M., Shimray, C.A., Indrani, D. \& Manonmani, H. (2014): Reduction of acrylamide formation in sweet bread with L-asparaginase treatment. Food Bioprocess Tech., 7, 741-748.

Lazaridou, A., Duta, D., Papageorgiou, M., Belc, N. \& Biliaderis, C. (2007): Effects of hydrocolloids on dough rheology and bread quality parameters in gluten-free formulations. J. Food Eng., 79(3), 1033-1047.

Mottram, D.S., Wedzicha, B.L. \& Dodson, A.T. (2002): Food chemistry: Acrylamide is formed in the Maillard reaction. Nature, 419(6906), 448-449.

Najafabadi, L.I., Le-Bail, A., Hamdami, N., Monteau, J.-Y. \& Keramat, J. (2014): Impact of baking conditions and storage temperature on staling of fully and part-baked Sangak bread. J. Cereal Sci., 60(1), 151-156.

Pedreschi, F., KaAck, K. \& Granby, K. (2008): The effect of asparaginase on acrylamide formation in French fries. Food Chem., 109(2), 386-392.

Pedreschi, F., Mariotti, S., Granby, K. \& Risum, J. (2011): Acrylamide reduction in potato chips by using commercial asparaginase in combination with conventional blanching. LWT - Food Sci. Technol., 44, 14731476.

Pourfarzad, A., Khodaparast, M.H.H., Karimi, M., Mortazavi, S.A., Davoodi, M.G., Sourki, A.H., Jahromi, R. \& Hossein, S. (2011): Effect of polyols on shelf-life and quality of flat bread fortified with soy flour. J. Food Proc. Eng., 34, 1435-1448

Rosén, J. \& Hellenäs, K.-E. (2002): Analysis of acrylamide in cooked foods by liquid chromatography tandem mass spectrometry. Analyst, 127, 880-882.

Sabovics, M., Straumite, E. \& Galoburda, R. (2014): The influence of baking temperature on the quality of triticale bread. FoodBalt 2014 Conference Proceedings, Jelgava. pp. 228-233.

ŞENYUVA, H.Z. \& GöKMEN, V. (2005): Study of acrylamide in coffee using an improved liquid chromatography mass spectrometry method: Investigation of colour changes and acrylamide formation in coffee during roasting. Food Addit. Contam., 22(3), 214-220.

Surdyk, N., Rosén, J., Andersson, R. \& Åman, P. (2004): Effects of asparagine, fructose, and baking conditions on acrylamide content in yeast-leavened wheat bread. J. Agr. Food Chem., 52, 2047-2051. 